\title{
Jurist-Diction
}

Volume 1 No. 1, September 2018

Article history: Submitted 2 August 2018; Accepted 15 August 2018; Available online 3 September 2018

\section{KERJASAMA INDONESIA DENGAN LEMBAGA-LEMBAGA TERKAIT DALAM PENANGANAN PENGUNGSI}

\author{
Mohamad Iqbal Jamilurir Rachman \\ mohamadiqbaljr@gmail.com \\ Universitas Airlangga
}

\begin{abstract}
Refugee is one of results of a violation of basic humanitarian values. At the international level, the instruments governing refugees are the 1951 Geneva Convention and the 1967 New York Protocol. In addressing refugee issues, the UN established an international organization focused specifically on the issue which is UNHCR. At the national level of Indonesia, the handling of refugees is governed by Presidential Regulation no. 125 of 2016 on The Handling of Refugees from Abroad. The Refugee Status Determination in Indonesia is given to UNHCR considering that Indonesia is not a party to the related international instruments. There are other institutions which contribute in the handling of refugees in Indonesia other than UNHCR, namely IOM and ICRC. Indonesia has established cooperation with these Institutions and continues to the present day. However, these cooperations need to be improved due to several problems arising in the refugee handling process.
\end{abstract}

Keywords: Refugees;1951 Geneva Conventions; Cooperation; Institutions.

\begin{abstract}
Abstrak
Pengungsi merupakan salah satu akibat dari bentuk pelanggaran terhadap nilai-nilai dasar kemanusiaan. Di tataran internasional, instrumen yang mengatur mengenai pengungsi adalah Konvensi Jenewa 1951 dan Protokol New York 1967. Dalam penanganan permasalahan pengungsi, PBB membentuk suatu organisasi internasional yang berfokus dalam isu tersebut yaitu UNHCR. Di tataran nasional Indonesia, penanganan pengungsi diatur dalam Peraturan Presiden No. 125 Tahun 2016 tentang Penanganan Pengungsi Luar Negeri. Terkait penentuan atau penetapan status pengungsi di Indonesia diserahkan kepada UNHCR mengingat Indonesia bukan negara pihak instrument internasional terkait. Ada lembaga lain yang turut andil dalam penanganan pengungsi di Indonesia selain UNHCR, yaitu IOM dan ICRC. Indonesia telah menjalin kerjasama dengan lembaga-lembaga ini dan berlangsung hingga sekarang. Namun kerjasama-kerjasama tersebut memerlukan peningkatan dikarenakan beberapa permasalahan muncul dalam proses penanganan pengungsi.
\end{abstract}

Kata Kunci: Pengungsi; Konvensi Jenewa 1951; Kerjasama; Lembaga-Lembaga.

\section{Pendahuluan}

Pengungsi merupakan salah satu akibat dari bentuk pelanggaran terhadap nilai-nilai dasar kemanusiaan yang tercantum dalam Universal Declaration of Human Rights $1948^{1}$ (selanjutnya disebut Deklarasi Hak Asasi Manusia Universal 1948). Seperti yang telah dinyatakan dalam Deklarasi tersebut bahwa pada setiap

${ }^{1}$ Universal Declaration of Human Rights 1948, proclaimed by United Nations General Assembly Resolution No. 217 A, 10 December 1948. 
individual melekat pada dirinya suatu hak, dimana mereka dapat mengekspresikan tiap hal yang ada tanpa adanya suatu pembedaan baik ras, jenis kelamin, bahasa, agama, pandangan poltitik, dan status kebangsaan dengan tetap memperhatikan ketentuan-ketentuan dimana yurisdiksi negara berlaku serta hak-hak tersebut diakui oleh ketentuan hukum internasional. ${ }^{2}$

Seiring dengan berkembangnya isu pengungsi di tataran regional dan internasional, langkah penyelesaian pun mulai diharapkan untuk segera dilakukan oleh negara-negara. Sebagai langkah awal, Perserikatan Bangsa-Bangsa (PBB) menyelenggarakan United Nations Conference of Plenipotentiaries on The Status of Refugees and Stateless Persons berdasarkan resolusi Majelis Umum Nomor 429 (V). Pertemuan tersebut meghasilkan suatu konvensi tentang Status Pengungsi atau Convention Relating to the Status of Refugees $1951^{3}$ (selanjutnya disebut Konvensi Jenewa 1951) yang dinyatakan berlaku pada tanggal 22 April $1954 .{ }^{4}$

PBBmembentuk suatu organisasi internasional khususyang bertanggungjawab dalam penanganan pengungsi secara internasional. Organisasi tersebut dinamakan United Nations High Commissioner for Refugees (selanjutnya disebut UNHCR). Organisasi internasional ini secara khusus menangani pengungsi, pencari suaka, orang-orang tanpa kewarganegaran, dan pengungsi internal. Tugas dari UNCHR meliputi tentang penentuan status pengungsi, relasi dengan pemerintah dan peningkatan kapasitas, kerjasama dan perlindungan berbasis komunitas, solusi komprehensif, dan mencegah keadaan tanpa kewarganegaraan. ${ }^{5}$

Terlepas dari banyaknya negara yang tergabung dalam organisasi dan meratifikasi konvensi, permasalahan tetap muncul ketika ada beberapa negara yang sering menjadi tujuan para pengungsi, tetapi belum mengadopsi Konvensi Jenewa

\footnotetext{
${ }^{2}$ Ibid., Ps. 2

${ }^{3}$ Convention Relating to the Status of Refugees 1951, Registration Number 2545, UNTS Volume Number 189, entry into force on 22 April 1954.

${ }^{4}$ Sri Badini Amidjojo, Perlindungan Hukum Terhadap Pengungsi Berdasarkan Konvensi Jenewa 1951, Badan Pembinaan Hukum Nasional Departemen Kehakiman dan Hak Asasi Manusia Republik Indonesia (2004).[2].

5 United Nations High Commisioner for Refugees (UNCHR), “Tentang United Nations High Commisioner for Refugees”, http://www.unhcr.org/id/, accessed pada tanggal 8 November 2017.
} 
1951 dan Protokol New York 1967 dalam hukum nasional seperti halnya Indonesia. Indonesia perlu membentuk suatu aturan yang berkenaan dengan penanganan pengungsi luar. Sehingga, pada tahun 2016 disahkanlah Peraturan Presiden Nomor 125 Tahun 2016 tentang Penanganan Pengungsi dari Luar Negeri.

Mengingat Indonesia bukan merupakan negara peratifikasi Konvensi Jenewa 1951 dan Protokol New York 1967 dan tidak mempunyai kapasitas dalam penentuan status pengungsi, Indonesia menjalin kerjasama dengan UNHCR. Berdasarkan lampiran Resolusi 428 (V) Majelis Umum PBB yang diadopsi pada tanggal 14 Desember 1950, Majelis Umum meminta Pemerintah untuk bekerjasama dengan UNHCR dalam pelaksanaan fungsinya mengenai pengungsi yang berada di bawah kompetensi Kantor tersebut. ${ }^{6}$ Hal tersebut juga ditekankan kembali dalam ketentuan UNHCR Statute ${ }^{7}$ (selanjutnya disebut Statuta UNHCR) pada pasal 1 yang menyatakan UNHCR turut membantu pemerintah negara-negara dalam rangka penanganan pengungsi. Peraturan Presiden Nomor 125 Tahun 2016 mengatur hal serupa pada Pasal 2 ayat (1).

Selain UNHCR, pada faktanya ada lembaga-lembaga lain yang terkait dalam penanganan pengungsi di skala global maupun skala nasional yaitu International Organization of Migration (selanjutnya disebut IOM) yang dalam hal ini berfokus dalam isu migrasi, International Committee of Red Cross (selanjutnya disebut ICRC) yang berfokus pada isu perlindungan, dan lembaga-lembaga lain yang menaruh perhatian khusus terhadap isu pengungsi. Tentunya Indonesia juga sangat disarankan untuk melakukan kerjasama dengan IOM, ICRC, dan pihak-pihak lainnya yang berkaitan dengan isu pengungsi sesuai yang diamanatkan pasal 2 ayat (1) dan ayat (2) Peraturan Presiden No. 125 Tahun 2016.

Urgensi mengenai kerjasama Indonesia dengan lembaga-lembaga terkait dalam penanganan pengungsi di Indonesia adalah bahwa pengungsi luar negeri tersebut

${ }^{6}$ United Nations General Assembly (UNGA) Fifth Session, General Assembly Resolution No. 428 (V) 14 December 1950, 14 December 1950, http://www.unhcr.org/refworld/docid/ 3b00f08a27. html, accessed pada 8 November 2017.

7 Statute of the Office of the United Nations High Commissioner for Refugees (UNHCR), proclaimed by UNGA Resolution 428 (V0 14 December 1950).[4]. 
berhak atas hak-hak dasar sesuai dengan apa yang diamanatkan dalam Deklarasi Hak Asasi Manusia Universal dan instrumen-instrumen internasional lainnya yag berkenaan dengan isu pengungsi. Untuk mewujudkan atau mencapai tujuan-tujuan sesuai dengan yang diamanatkan, diperlukan kerjasama yang konstruktif antar lembaga-lembaga yang bersentuhan langsung maupun tidak langsung dengan isu pengungsi ini. Khususnya untuk pencarian solusi permanen bagi pengungsi dalam rangka untuk mengurangi jumlah pengungsi yang mungkin akan bertambah di masa yang akan datang.

\section{Rumusan Masalah}

Dari latar belakang yang telah diuraikan di atas, hal-hal yang ingin dikaji dan dibahas dalam penulisan ini adalah:

1. Pengaturan dalam Hukum Internasional dan Nasional mengenai Pengungsi.

2. Kerjasama Indonesia dan Lembaga-Lembaga Terkait dalam Penanganan Pengungsi di Indonesia.

\section{Metode Penelitian}

Tipe penelitian yang digunakan dalam penelitian hukum yang disusun dengan menggunakan pendekatan konseptual dan pendekatan perundang-undang.

\section{Pengungsi Menurut Ketentuan Hukum Internasional}

Konvensi Jenewa 1951 adalah landasan utama perlindungan secara internasional yang digagas oleh PBB dan telah diikuti oleh beberapa negara yang ada di dunia. Konvensi ini dibentuk berdasarkan pasal 14 Deklarasi Universal Hak Asasi Manusia 1948 yang menyatakan dan mengakui adanya hak untuk mencari suaka dari persekusi di negara lain. ${ }^{8}$ Dalam prosesnya, Konvensi Jenewa 1951 mulai diadopsi oleh negaranegara pada tanggal 28 Juli 1951 oleh United Nations Conference of Plenipotentiaries on the Status of Refugees and Stateless dan mulai berlaku pada tanggal 22 April $1954 .{ }^{9}$

8 United Nations General Assembly (UNGA) Fifth Session, Loc.Cit.

${ }^{9}$ Introductory Note by the Office of the United Nations High Commissioner for Refugees (UNHCR), Konvensi Jenewa 1951 dan Protokol New York (1967).[5]. 
Dibandingkan dengan instrument-instrumen internasional sebelumnya, Konvensi Jenewa 1951 merupakan suatu bentuk kemajuan dikarenakan Konvensi ini memberikan kodifikasi yang paling lengkap mengenai pengaturan permasalah pengungsi di tingkat internasional. ${ }^{10}$ Selain yang telah dijelaskan sebelumnya, kemajuan yang ada dalam Konvensi Jenewa 1951 meliputi:

1. Konvensi memberikan definisi tunggal dari kata "pengungsi" pada pasal 1;

2. pengaturan status yuridis pengungsi;

3. pengaturan tentang kartu tanda pengenal, dokumen perjalanan, serta hal-hal administratif lainnya;

4. Anjuran negara untuk bekerjasama dengan UNHCR dalam melaksanakan kewajibannya, serta memfasilitasi tugas supervise dalam penerapan Konvensi Jenewa $1951 .{ }^{11}$

Kemudian, Konvensi Jenewa 1951 mengalami perbaikan dengan penyusunan Protokol New York 1967 dan merupakan instrumen yang berdiri sendiri. ${ }^{12}$ Maksud dari instrumen yang berdiri sendiri adalah bahwa Negara boleh ikut serta sebagai Negara Pihak Protokol New York 1967 tanpa harus menjadi peserta pada Konvensi Jenewa $1951 .^{13}$ Protokol ini meniadakan batas waktu dan batas geografis definisi pengungsi yang terdapat dalam Konvensi Jenewa 1951. ${ }^{14}$ Dengan adanya Protokol New York 1967, jumlah Negara yang ikut serta pada Protokol menjadi meningkat lebih dari 100 negara. ${ }^{15}$

Dalam penanganan terhadap pengungsi, tindakan yang akan diambil didasarkan pada beberapa prinsip yaitu non-refoulment principle, non-discrimination principle, dan non-penalization principle. Prinsip non-refoulment mulai dikenal semenjak prinsip ini dimasukkan dalam Konvensi Jenewa $1951 .{ }^{16}$ Prinsip tersebut dibangun

\footnotetext{
${ }^{10}$ Ibid.[6].

${ }^{11}$ Achmad Romsan et. al., Pengantar Hukum Pengungsi Internasional, UNHCR. 2003.[88]

12 Sigit Riyanto, Urgensi Legislasi Hukum Pengungsi dan Kendalanya di Indonesia, Indonesian Journal of International Law, Vol. 2, No. 1 (2004).[72].

${ }^{13}$ Final Act of the United Nations Conference of Plenipotentiaries on the Status of Refugees and Stateless Persons, Konvensi Jenewa 1951 dan Protokol New York (1967).[8].

${ }^{14}$ Sigit Riyanto, Op.Cit.[72].

${ }_{15}$ UNHCR, Training Module RLD I, An Introduction to the International Protection of Refugees, UNHCR (1992).[17].

${ }^{16}$ Winner Nabila Jatyputri, Penerapan Prinsip Non-Discrimination bagi Pengungsi Rohingya di Indonesia, Skripsi, Fakultas Hukum Universitas Airlangga.2015.[41]. dikutip dari Sigit Riyanto, Prinsip Non-Refoulment dan Relevansinya dalam Sistem Hukum Internasional, mimbar hukum, Vol. 22, Nomor 3 (Oktober 2010).[434-449].
} 
atas dasar ketidakberpihakan serta tanpa diskriminasi. ${ }^{17}$ Sebagaimana diatur dalam Pasal 33 ayat (1) Konvensi Jenewa 1951, prinsip ini merupakan bentuk larangan suatu negara yang menjadi pihak dalam Konvensi Jenewa 1951 dan Protokol New York 1967 untuk mengusir atau memulangkan kembali pengungsi dengan cara apapun ke perbatasan wilayah-wilayah dimana hidup dan kebebasan pengungsi tersebut terancam karena adanya penganiayaan berdasarkan ras, agama, kebangsaan, keanggotaan pada kelompok sosial tertentu atau pendapat politiknya. Prinsip ini merupakan tindakan minimum yang bisa diberikan untuk alasan kemanusiaan kepada orang yang terpaksa atau dipaksa keluar dari negara tempat ia tinggal. ${ }^{18}$

Prinsip non-discrimination mengamanatkan bahwa dalam melakukan penanganan permasalahan pengungsi, semua proses yang dilalui harus dilakukan tanpa adanya diskriminasi baik karena alasan ras, agama, negara asal, jenis kelamin, cacat, seksualitas atau alasan diskriminasi lainnya. Dalam Konvensi Jenewa 1951 sendiri dijelaskan dalam pasal 3 mengenai prinsip non diskriminasi yaitu negaranegara pihak dari Konvensi Jenewa 1951 akan menerapkan ketentuan-ketentuan dalam Konvensi tersebut pada para pengungsi tanpa adanya diskriminasi.

Prinsip non-penalization dinyatakan dalam Pasal 31 Konvensi Jenewa 1951 yaitu yang menyatakan bahwa negara-negara pihak tidak dapat mengenakan hukuman pada para pengungsi, karena masuk atau keberadaannya secara tidak sah atau illegal dan tanpa izin serta yang datang langsung dari wilayah dimana hidup atau kebebasan mereka terancam seperti yang dinyatakan pasal 1 Konvensi Jenewa 1951. Namun, prinsip tersebut dapat diberlakukan dengan syarat pengungsi-pengungsi tersebut segera melaporkan diri pada otoritas terkait dan memberitahukan alasan yang sepatutnya atas masuknya atau keberadaan mereka secara tidak sah dan tanpa izin tersebut.

Dalam proses penetapan atau penentuan status pengungsi, UNHCR memegang peranan penting selama proses tersebut. Dalam mekanisme UNHCR,

\footnotetext{
${ }^{17}$ Reza Fachrurrahman, Penerapan Prinsip Non-Refoulment Terhadap Pengungsi di Indonesia Sebagai Negara Yang Bukan Merupakan Peserta Konvensi Jenewa Tahun 1951 Mengenai Status Pengungsi, JOM Fakultas Hukum, Vol. III, No.2 (Oktober 2016).[7].

18 Jovan Patrnogic, Introduction to International Refugee Law, International Institute of Humanitarian Law, (San Remo 1996).[58].
} 
status pengungsi didapat setelah seorang pencari suaka yang meminta perlindungan dievaluasi melalui prosedur Refugee Status Determination (RSD) atau penentuan status pengungsi. ${ }^{19}$ Proses penentuan atau penetapan tersebut bisa juga dilakukan oleh negara jika negara tersebut merupakan negara pihak dari instrument internasional seperti Konvensi Jenewa 1951 dan Protokol New York 1967 maupun instrument regional seperti Konvensi OPA dan Deklarasi Kartagena. Dalam penetapan atau penentuan status pengungsi, dapat digunakan kriteria yang terdiri dari: ${ }^{20}$

a. Faktor Subjektif: faktor yang menentukan apakah pada diri seseorang ada rasa takut atau khawatir akan adanya persekusi. Ketakutan tersebut dinilai dari takut terhadap tuntutan negaranya dan terancam kebebasannya. ${ }^{21}$

b. Faktor Objektif: berkenaan dengan keadaan asal pengungsi, tentang fakta mengenai apakah benar-benar terjadi persekusi atas orang-orang tertentu. ${ }^{22}$ Persekusi tersebut terjadi akibat perbedaan ras, agama, atau hal-hal seperti yang diatur dalam Konvensi Jenewa 1951 dan Protokol New York 1967.

Dalam proses penentuan atau penetapan status pengungsi, akan dilalui beberapa tahap yang dirumuskan dengan bagan sebagai berikut:

\section{Bagan 1}

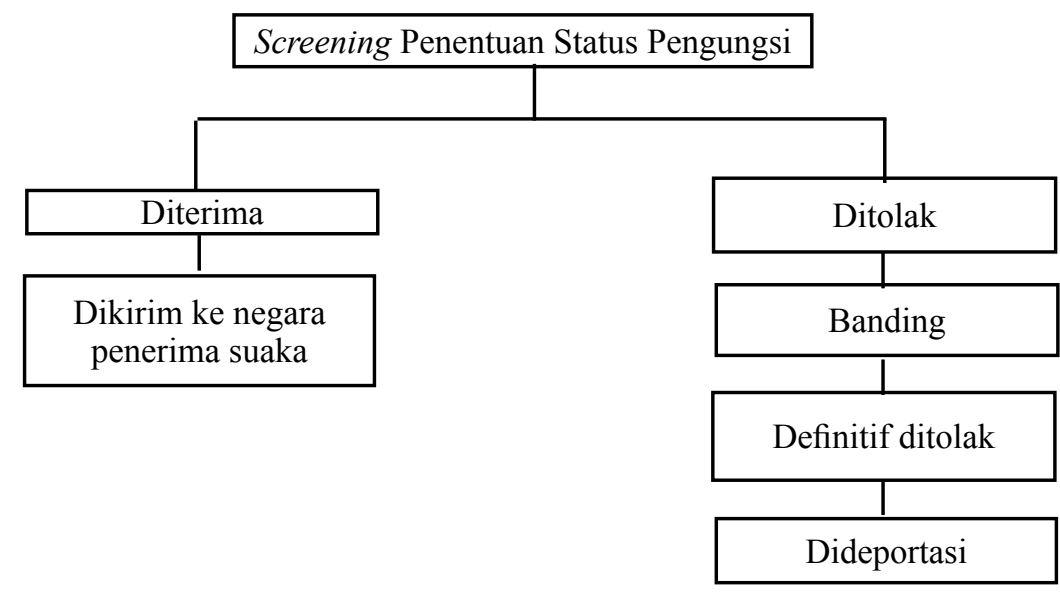

${ }^{19}$ UNHCR, Procedural Standards for Refugee Status Determination under UNHCR's Mandate, UNHCR, Jenewa, 2005, unit 6.

${ }^{20}$ Lembaga Studi dan Advokasi Masyarakat (ELSAM), Perlindungan Pengungsi (Refugee) Menurut Hukum Internasional, http://referensi.elsam.orid/wp-content/uploads/2014/ 10/ Perlindungan-Pengungsi-Refugee-Menurut-Hukum-Internasional. pdf, Oktober 2014, accessed pada 2 Februari 2018.

${ }^{21}$ Ibid.

${ }^{22}$ Ibid. 
Sumber: Hukum Pengungsi Internasional, Wagiman, 2012..23

Sebelum dilaksakan screening seperti yang tercantum pada bagan di atas, akan dilakukan screening sementara terlebih dahulu dalam rangka untuk mengelompokkan pemohon status pengungsi.

\section{Bagan II}

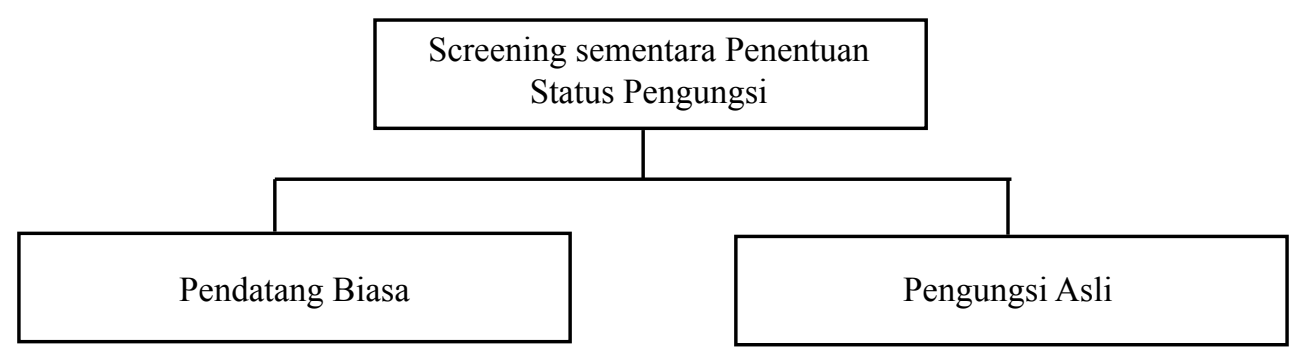

Sumber: Hukum Pengungsi Internasional, Wagiman, 2012..4

Perlu ditekankan bahwa seseorang atau sekelompok orang dapat memperoleh status pengungsi jika memenuhi 4 elemen berikut, yaitu: ${ }^{25}$

a. seseorang atau sekelompok orang tersebut berada di luar wilayah negara asalnya;

b. seseorang atau sekelompok orang tersebut tidak dapat atau tidak ingin menggunakan perlindungan dari negara asalnya, atau kembali kesana;

c. ketidakmampuan atau ketidakmauan seperti yang dijelaskan di atas disebabkan oleh well-founded fear akan penganiayaan;

d. penganiayaan tersebut didasarkan pada alasan ras, agama, kebangsaan, keanggotaan pada kelompok sosial tertentu atau pendapat politik.

Elemen-elemen di atas dapat dibuktikan lewat Teori Tiga Tahap yang diperkenalkan oleh Jean-Yves Carlier, yaitu the Risk (apakah resiko benar-benar ada), the Persecution (apakah persekusi benar-benar ada), the Proof (apakah ada bukti-bukti atas resiko dan persekusi tersebut). ${ }^{26}$

Setelah melalui proses penetapan atau penentuan status pengungsi, orangorang yang mendapatkan status pengungsi akan memperoleh beberapa solusi sesuai dengan yang diatur dalam Statuta UNHCR yaitu voluntary repatriation, local integration dan resettlement. Voluntary Repatriation (Repatriasi Sukarela) adalah

\footnotetext{
${ }^{23}$ Wagiman, Hukum Pengungsi Internasional (Sinar Grafika 2001).[108].

${ }^{24}$ Ibid

${ }^{25}$ Guy s. Goodwin-gill, The Refugee in International Law Second Edition( Clarendon Press, Oxford 1998).[19-20].

26 Wagiman, Op.Cit.[109].
} 
solusi penanganan pengungsi dengan cara memulangkan kembali pengungsi secara sukarela untuk kembali ke negara asalnya. Local Integration (Integrasi Lokal) adalah solusi penanganan pengungsi dengan cara mengintegrasikan pengungsi dengan masyarakat lokal dan menjadi bagian dari negara pemberi suaka. Resettlement adalah solusi penanganan pengungsi dengan cara menempatkan pengungsi di negara ketiga yang biasanya adalah negara pihak dari Konvensi Jenewa 1951 dan/ atau Protokol New York 1967.

\section{Pengungsi Menurut Ketentuan Hukum Nasional}

Peraturan Presiden Nomor 125 Tahun 2016 merupakan peraturan pertama yang mengatur mengenai penanganan permasalahan pengungsi di Indonesia. Namun, perlu dipahami bahwa Peraturan Presiden tersebut bukan merupakan bentuk ratifikasi yang dilakukan Indonesia terhadap instrument internasional tentang pengungsi yaitu Konvensi Jenewa 1951 dan Protokol New York 1967.

Dalam Peraturan Presiden tersebut dijelaskan bahwa ada beberapa instansi dalam negeri yang nantinya akan turut bekerjasama untuk penanganan pengungsi di Indonesia. Dalam hal pencarian dan pertolongan seperti yang dinyatakan dalam Pasal 7, instansi yang akan terlibat adalah Tentara Nasional Indonesia (TNI), Kepolisian Negara Republik Indonesia, Kementerian yang menyelenggarakan urusan di bidang perhubungan, lembaga yang menyelenggarakan urusan di bidang keamanan dan keselamatan laut atau yang disebut Badan Keamanan Laut, serta kementerian/lembaga pemerintah non kementerian yang melaksanakan tugas di perairan wilayah Indonesia. Kemudian pada Pasal 10, dinyatakan Kementerian Hukum dan HAM turut andil dalam penanganan pengungsi khususnya bagian imigrasi yang membawahi Rumah Detensi Imigrai atau RUDENIM. Terdapat pula peran dari Kementerian Luar Negeri seperti yang tertera dalam Pasal 15 dalam rangka untuk penanganan pengungsi yang berkaitan dengan bidang hubungan luar negeri dan politik luar negeri.

Dalam penetapan atau penentuan status pengungsi yang berada di Indonesia, pemerintah memberikan kewenangan untuk melakukan hal tersebut kepada 
UNHCR. Hal ini mengingat Indonesia bukan merupakan negara peratifikasi Konvensi Jenewa 1951 dan Protokol New York 1967 dan mengakibatkan Indonesia tidak dapat membuat sistem tersendiri untuk menentukan status pengungsi yang berada di wilayahnya. Peraturan Presiden Nomor 125 Tahun 2016 tentang Penanganan Pengungsi Luar Negeri tidak mengatur penetapan atau penentuan status tersebut. Berikut ini skema penetapan status pengungsi hasil wawancara dengan Kepala Bagian Penanganan Orang Asing di Kantor Imigrasi Klas II Blitar dan ditambahkan oleh Kepala Kantor Rumah Detensi Imigrasi Surabaya. ${ }^{27}$

\section{Bagan III}

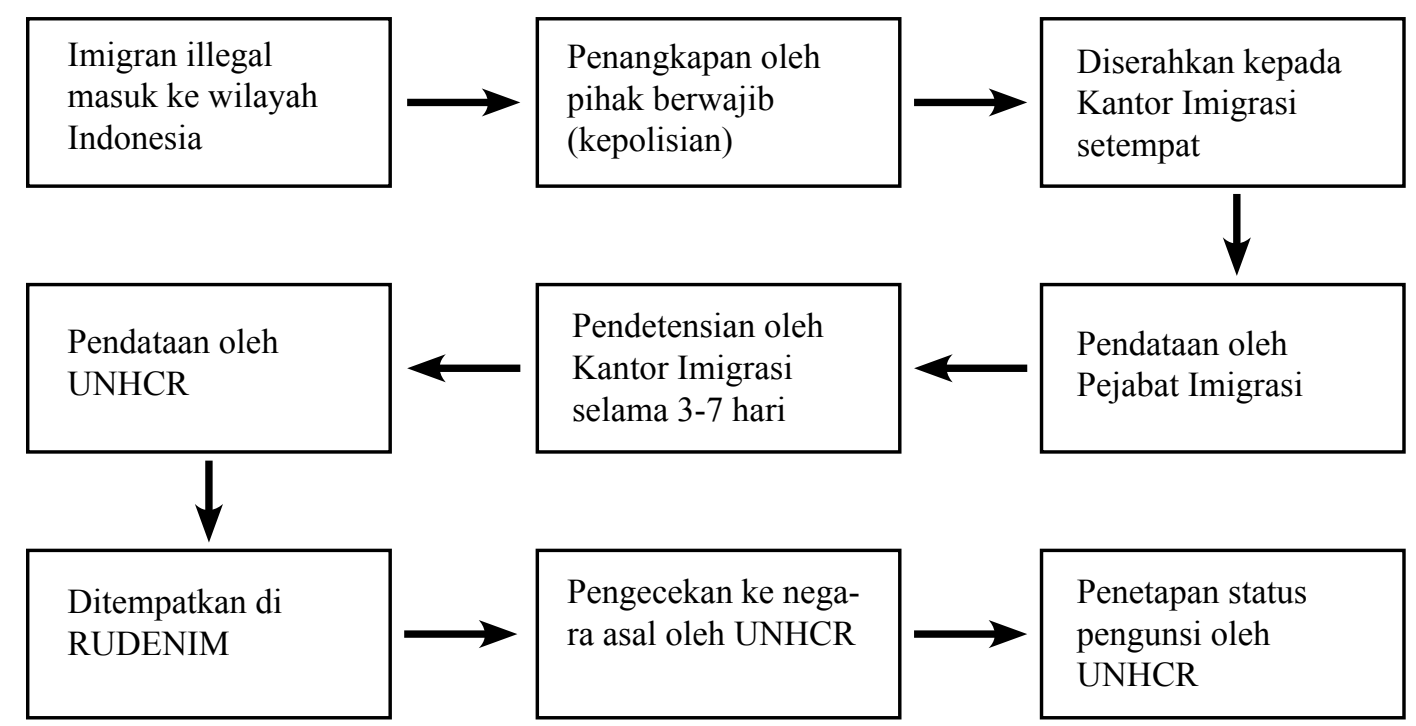

Sumber: Wawancara Kepala Bagian Penanganan Orang Asing Kantor Imigrasi Klas II Blitar dan Kepala Kantor Rumah Detensi Imigrasi Surabaya

Selain yang sudah dijelaskan sesuai wawancara di atas, dijelaskan pula bagan mekanisme penetapan status pengungsi dalam Buku karangan Bapak Wagiman, salah satu ahli dari hukum pengungsi.

Berikut bagan tersebut:

\footnotetext{
${ }^{27}$ Pratiwi Ningrum, Op. Cit., [53] dikutip dari wawancara dengan kepala bagian penanganan orang asing di Kantor Imigrasi Klas II Blitar, Blitar, Tanggal 23 Januari 2001 serta ditambahkan oleh Kepala Kantor Rumah Detensi Imigrasi Surabaya April 2012.
} 


\section{Bagan IV}

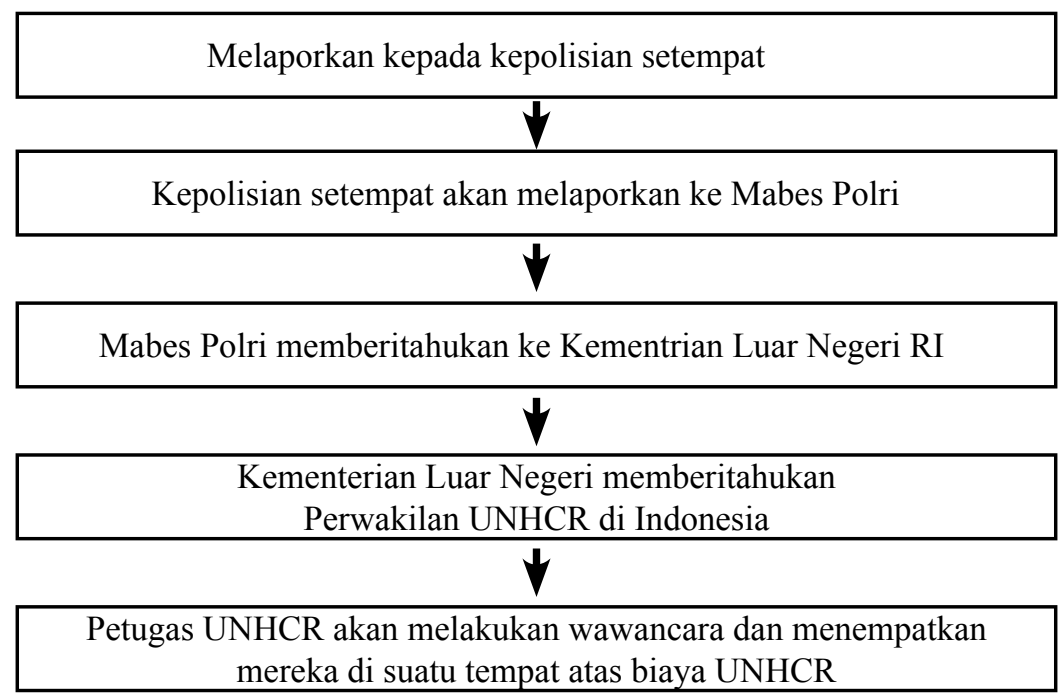

Sumber: Hukum Pengungsi Internasional, Wagiman, 2012. ${ }^{28}$

\section{Kerjasama Indonesia dan Lembaga-Lembaga Terkait dalam Penanganan Pengungsi di Indonesia}

Indonesia telah menjalin kerjasama dengan UNHCR, IOM, dan ICRC dalam rangka pencarian solusi permanen untuk pengungsi. Terlebih kerjasama ini juga telah diamanatkan dalam Peraturan Perundang-undangan yaitu Peraturan Presiden No. 125 Tahun 2016 tentang Penanganan Pengungsi dari Luar Negeri. Sesuai yang diamanatkan Pasal 2 ayat (1) dan ayat (2), Undang-Undang Nomor 37 Tahun 1999 Pasal 12 ayat (1). ${ }^{29}$

Kerjasama Indonesia dan UNHCR telah berlangsung sejak tahun 1979 yaitu lewat Agreement between the Government of the Republic of Indonesia and United Nations High Commissioner for Refugees regarding the Establishment of the Office of the UNHCR Representative for Indonesia yang ditandatangani pada tanggal 15 Juni 1979. Pada intinya, perjanjian atau kesepakatan tersebut menyatakan bahwa UNHCR diperbolehkan untuk membuka kantor regional di Indonesia dan turut membantu Indonesia dalam penanganan masalah pengungsi di wilayah Indonesia.

\footnotetext{
${ }^{28}$ Wagiman, Op.Cit.[33].

29 Undang-Undang Nomor 37 Tahun 1999 tentang Hubungan Luar Negeri (Lembaran Negara Republik Indonesia Tahun 1999 Nomor 156, Tambahan Lembaran Negara Republik Indonesia Nomor 3882).
} 
Kerjasama penanganan pengungsi pertama kalinya dilakukan pada saat kedatangan pengungsi dari Vietnam. Dalam rangka untuk penampungan pengungsi tersebut, Indonesia menyediakan Pulau Galang untuk ditempati pengungsi ${ }^{30}$ dan mengambil kebijakan untuk mempercepat proses repatriasi atau pemulangan secara sukarela bagi pengungsi Vietnam tersebut ke negara asalnya. ${ }^{31}$ UNHCR turut serta bekerjasama dengan Indonesia untuk proses pemulangan tersebut dengan memberikan bantuan dana bagi pengungsi yang berkenaan dengan pemulangan mereka yaitu seperti uang paket dan uang penerbangan. ${ }^{32}$ Selain bantuan dana tersebut, tentunya UNHCR juga melaksanakan tugasnya dalam rangka untuk penetapan status pengungsi bagi orang-orang yang memenuhi kriteria pengungsi baik menurut instrument internasional maupun instrument regional yang diakui.

Penetapan tersebut dilakukan oleh UNHCR dikarenakan Indonesia bukan merupakan negara pihak Konvensi Jenewa 1951 dan Protokol New York 1967. Bagi negara pihak dari instrument internasional tersebut, tentunya negara pihak dapat melakukan prosedur penentuan status pengungsi secara mandiri. Meskipun begitu, UNHCR juga tetap bekerjasama dengan Indonesia terkait permohonan baru dari status pengungsi. Dari pihak Indonesia akan membawa permohonan baru pengungsi di Indonesia ke pihak UNHCR. Kemudian jika status pengungsi disetujui, pihak UNHCR akan memberikan izin tinggal di Indonesia dengan sepersetujuan Pemerintah Indonesia sampai dengan pengungsi tersebutmendapatkan penempatan. ${ }^{33}$ Pada tahun 2015, Indonesia dan UNHCR kembali menjalin kerjasama yang dalam hal ini, Indonesia diwakili oleh Komisi Nasional Hak Asasi Manusia (Komnas HAM) Indonesia. ${ }^{34}$ Kedua pihak menandatangani Nota Kesepahaman untuk meningkatkan advokasi dan langkah lainnya yang dirancang untuk perlindungan

\footnotetext{
30 Moh. Fandik, Penampungan Orang Vietnam di Pulau Galang 1975-1979, AVATARA e-Journal Pendidikan Sejarah Universitas Negeri Surabaya, Vol. 1, No.1 (Januari 2013).[164].

${ }^{31}$ Achmad Romsan et al, Op. Cit.[190].

32 Ibid.[191-192].

33 Wagiman, Op.Cit.[200].

${ }^{34}$ Mitra Suryono, UNHCR dan Komisi Nasional Hak Asasi Manusia Indonesia Bekerja Sana untuk Lindungi Hak Asasi Manusia bagi Pengungsi dan Lainnya, http://www.unhcr.org/id/wp-content/uploads/sites/42/2017/05/Siaran-Pers-MoU-Signing-KomNasHAM.pdf, 28 Juli 2015, accessed pada 23 Juni 2018.
} 
hak asasi manusia para pengungsi dan pihak lain yang berada di bawah mandat UNHCR di Indonesia. ${ }^{35}$ Kemudian kedua belah pihak, baik UNHCR dan Indonesia, membentuk pula suatu jaringan lembaga guna koordinasi mengenai penanganan penyelundupan manusia, pengungsi, dan pencari suaka. Jaringan lembaga tersebut disebut dengan Desk Koordinasi Penanganan Penyelundupan Manusia, Pengungsi, dan Pencari Suaka (P2MP2S). ${ }^{36}$

Kerjasama antara Indonesia dengan IOM terus terjalin dan berkelanjutan dalam hal penanganan masalah pengungi di wilayah Indonesia. Pada tahun 2000 kedua belah pihak bersepakat untuk menandatangani perjanjian kerjasama Cooperation Arrangement between the Government of Indonesia and International Organization for Migration. ${ }^{37}$ Perjanjian yang ditandatangani tersebut membahas tentang kerjasama dalam memerangi penyelendupan manusia di Indonesia. ${ }^{38}$ Selain itu, dalam perjanjian tersebut juga disepakati bahwa IOM akan memberikan bantuan dan kerjasama teknis dalam upaya menanggulangi masalah-masalah migrasi, termasuk penanganan permasalahan pengungsi. ${ }^{39}$ Kerjasama IOM dengan Indonesia juga diwujudkan dengan partisipasi IOM dalam Desk Koordinasi Penanganan Penyelundupan Manusia, Pengungsi, dan Pencari Suaka (P2MP2S) bersama-sama dengan UNHCR. ${ }^{40}$ Pengembangan kerjasama antara Indonesia dengan IOM terus menerus dilakukan secara berkelanjutan oleh kedua belah pihak sendiri. Dibuktikan dengan adanya kolaborasi antara IOM Indonesia dengan Indonesia di beberapa Pertemuan Bilateral Tingkat Tinggi Imigrasi Indonesia dengan negara lain seperti

\footnotetext{
35 Eva Nila Sari, MoU Komnas HAM dan UNHCR Dorong Perlindungan Pengungsi dan Pencari Suaka, https://www.komnasham.go.id/index.php/news/2015/7/28/173/mou-komnas-ham-dan-unhcr-dorong-perlindungan-pengungsi-dan-pencari-suaka.html , 28 Juli 2015, accessed pada 23 Juni 2018.

${ }^{36}$ IOM Indonesia, January 2014 Newsletter "IOM di Indonesia”, http://indonesia.iom.int/ sites/default/files/January\%202014\%20Newsletter\%20Indonesian.pdf, Januari 2014, [3], accessed pada 25 Juni 2018.

37 Kementerian Luar Negeri Republik Indonesia, Pemerintah Indonesia Tandatangani Naskah Pengaturan Kerjasama untuk Penanganan Masalah Pengungsi, https://www.kemlu.go.id/ id/berita/siaran-pers/Pages/Pemerintah-Indonesia-Tandatangani-Naskah-Pengaturan-Kerjasama-untuk-Penanganan-Masalah-Pengungsi.aspx , 4 Oktober 2000, accessed pada 25 Juni 2018

${ }^{38}$ IOM Indonesia, Loc. Cit.

${ }^{39}$ Kementerian Luar Negeri Republik Indonesia, Loc. Cit.

${ }^{40}$ IOM Indonesia, Op. Cit., [3]
} 
Korea dan Thailand. ${ }^{41}$ Kerjasama terbaru yang dilakukan dengan IOM dan juga Australia adalah penyelenggaraan pertemuan Bali Process on People Smuggling, Trafficking in Persons and Related Transnational Crimes (selanjutnya disebut Bali Process) yang ke-6 (enam) pada Maret 2016. ${ }^{42}$ Pertemuan ini pertama kali digagas pada Februari 2002 dalam konferensi "Regional Ministerial Conference on People Smuggling, Trafficking in Persons and Related Transnational Crimes di Bali. ${ }^{43}$ Hasil dari pertemuan pada maret 2016 tersebut adalah kesepakatan untuk pembentukan mekanisme regional dalam mempercepat penanganan isu migrasi irregular dan mix migration, termasuk pencari suaka dan pengungsi. ${ }^{44}$ Kerjasama terbaru lainnya antara IOM dengan Indonesia adalah dalam bentuk kegiatan pelatihan manajemen perawatan imigran dan sosialisasi Peraturan Presiden No. 125 Tahun 2016 yang dilaksanakan pada bulan Juli 2017 di RUDENIM Kupang. ${ }^{45}$

ICRC pertama kali masuk di wilayah Indonesia pada tahun 1940, namun belum ada kerjasama formal antara kedua pihak. Seiring berjalannya waktu, ICRC telah melakukan dua perjanjian dengan Indonesia sampai tahun 1978. Yang pertama pada 1977 mengenai Kunjungan Tahanan. ${ }^{46}$ Yang kedua kesepakatan antara kedua pihak pada tahun 1987 yaitu berupa Agreement between the Government of the Republic of Indonesia and the International Committee of the Red-Cross on the Establishment of the ICRC Regional Delegation in Jakarta. Setelah penandatanganan perjanjian

41 Ibid.[6].

${ }^{42}$ Bali Process, Ministerial Conference and Senior Officials Meetings https://www.baliprocess. net/ministerial-conferences-and-senior-officials-meetings/, Maret 2016, accessed pada 25 Juni 2018.

${ }^{43}$ Tempo.co, Tak Lagi Usir Pengungsi, Australia Tunduk pada Bali Process, https://dunia. tempo.co/read/729969/tak-lagi-usir-pengungsi-australia-tunduk-pada-bali-process , 22 Desember 2015, accessed pada 25 Juni 2018.

44 Kementerian Luar Negeri Republik Indonesia, Bali Process Sepakati Mekanisme untuk Percepa Penanganan Migran Ireguler di Kawasan, https://www.kemlu.go.id/id/berita/Pages/ Bali-Process-Sepakati-Mekanisme-untuk-Percepat-Penangangan-Migran-Ireguler-di-Kawasan. aspx , 23 Maret 2016, accessed pada tanggal 25 Juni 2018.

${ }^{45}$ Kanwil NTT, Beerita Satuan Kerja Direktorat Jenderal Imigrasi Bersama IOM Adakan Pelatihan dan Sosialisasi di Rudenim Kupang, https: //ntt.kemenkumham.go.id/berita-kanwil/ berita-upt/3147-direktorat-jenderal-imigrasi-bersama-iom-adakan-pelatihan-dan-sosialisasi-di-rudenim-kupang, 13 Juli 2017, accessed pada 25 Juni 2018

46 ICRC Indonesia, Wawancara Kepala Delegasi Regional ICRC: Kenapa ICRC Masih Ada di Indonesia?, http://blogs.icrc.org/indonesia/wawancara-kepala-delegasi-regional-icrc-kenapa-icrc-masih-ada-di-indonesia/ 7 September 2011, accessed pada 26 Juni 2018. 
ini, ICRC Indonesia mulai melakukan misi kemanusiaannya di Indonesia.

Indonesia dan ICRC terus menerus berusaha meningkatkan kerjasama dari waktu ke waktu, terutama mengenai implementasi hukum humaniter internasional di Indonesia. Pada tahun 2011, Indonesia yang dalam hal ini diwakili oleh Badan Pembinaan Hukum Markas Besar Tentara Nasional Indonesia (Babinkum Mabes TNI) telah memformalkan kerjasama dengan ICRC melalui penandatanganan Nota Kesepahaman (MoU). ${ }^{47}$ Tujuan dari kerjasama ini adalah untuk diseminasi Hukum Humaniter Internasional di kalangan prajurit TNI. Diharapkan prajurit TNI dapat lebih paham mengenai bagaimana penerapan hukum humaniter internasional baik selama operasi militer untuk perang maupun operasi militer selain perang. ${ }^{48}$ Selain menjalin kerjasama dengan kalangan militer, ICRC juga melakukan kerjasama dengan institusi akademik dalam hal implementasi hukum humaniter internasional di Indonesia. Salah satu kerjasama yang dilakukan adalah dengan penandatanganan perjanjian antara Universitas Syiah Kuala dan ICRC yang dilakukan pada tanggal 4 September $2015 .{ }^{49}$

Secara tidak langsung, kerjasama-kerjasama ini juga membawa implikasi pada keberadaan pengungsi yang ada di wilayah Indonesia. Perlindungan terhadap pengungsi semakin terjamin tidak hanya pada masa damai, namun juga pada masa tidak damai atau berkonflik. Hal tersebut merujuk pada apa yang sudah dijelaskan sebelumnya, bahwa pengungsi berhak atas perlindungan jika terjadi konflik di suatu negara dengan dasar Konvensi Jenewa IV 1949.

Indonesia tetap beritikad baik untuk menangani pengungsi yang ada di wilayahnya terlepas dari posisi Indonesia yang bukan merupakan negara pihak dari Konvensi Jenewa 1951 dan/atau Protokol New York 1967. Sebagai negara transit, Indonesia telah berupaya untuk bekerjasama dengan lembaga-lembaga terkait dalam

${ }^{47}$ ICRC Indonesia, Babinkum TNI dan ICRC Formalkan Kerjasama, http://blogs.icrc.org/indonesia/babinkum-tni-dan-icrc-formalkan-kerjasama/, 7 September 2011, accessed pada 26 Juni 2018.

${ }^{48}$ Ibid.

49 ICRC Indonesia, ICRC Perkuat Kerjasama Akademik dengan Universitas Syah Kuala Aceh, http://blogs.icrc.org/indonesia/icrc-perkuat-kerjasama-akademik-dengan-universitas-syah-kuala-aceh/,7 September 2015, accessed pada 27 Juni 2018. 
penanganan pengungsi. Dalam hal ini, lembaga-lembaga tersebut merujuk pada UNHCR, IOM, dan ICRC. Seperti yang dijelaskan sebelumnya, telah ada beberapa bukti konkret kerjasama Indonesia dengan lembaga-lembaga tersebut. Meskipun sudah menjalin kerjasama dengan beberapa organisasi internasional, permasalahan pengungsi belum sepenuhnya dapat terselesaikan. Muncul beberapa permasalahan dalam proses penanganan pengungsi sejauh ini di wilayah Indonesia.

Permasalahan pertama yang terjadi adalah jumlah pengungsi yang terus menerus meningkat setiap bulannya. Peningkatan jumlah refugee ini tidak diimbangi dengan peningkatan jumlah resettlement atau penempatan di negara ketiga. Hal tersebut dapat dilihat pada table di bawah ini dan data resmi tersebut penulis dapat dari UNHCR Indonesia Monthly Statictical Report.

\section{Tabel 1}

\begin{tabular}{|c|c|c|c|c|}
\hline No & $\begin{array}{c}\text { Bulan dan } \\
\text { Tahun }\end{array}$ & $\begin{array}{c}\text { Jumlah Pengungsi } \\
\text { di Indonesia }\end{array}$ & $\begin{array}{c}\text { Jumlah Pencari } \\
\text { Suaka di } \\
\text { Indonesia }\end{array}$ & $\begin{array}{c}\text { Diberangkatkan untuk } \\
\text { Resettlement }\end{array}$ \\
\hline 1 & Januari & 8.039 & 6.386 & 40 \\
\hline 2 & Februari & 8.096 & 6.337 & 67 \\
\hline 3 & Maret & 8279 & 6191 & 14 \\
\hline 4 & April & 8513 & 5986 & 19 \\
\hline 5 & Mei & 8636 & 5701 & 75 \\
\hline 6 & Juni & 8819 & 5274 & 107 \\
\hline 7 & Juli & 8965 & 4904 & 223 \\
\hline 8 & Agustus & 8954 & 4722 & 162 \\
\hline 9 & September & 9097 & 4553 & 21 \\
\hline 10 & November & 9574 & 4193 & 20 \\
\hline
\end{tabular}

Sumber: UNHCR Indonesia Monthly Statistical Report January-September 2018 dan November 2018

Seperti yang sudah disampaikan sebelumnya bahwa dalam tabel tersebut dapat kita lihat jumlah pengungsi meningkat setiap bulannya. Salah satu penyebab terjadinya peningkatan tersebut adalah lamanya masa tunggu untuk proses resettlemet secara permanen. Tidak ada pengaturan yang jelas mengenai berapa lama pengungsi harus menunggu, sehingga terjadi penumpukan jumlah pengungsi dan akhirnya terjadi peningkatan setiap bulannya. Sehingga diperlukan suatu 
pengaturan mengenai masa tunggu pengungsi sampai mereka ditempatkan di negara ketiga yang dirumuskan oleh Indonesia dengan lembaga-lembaga yang terlibat.

Permasalahan kedua adalah penggunaan Rumah Detensi Imigrasi(RUDENIM) untuk tempat menetap pengungsi. Menurut Peraturan Menteri Hukum dan Hak Asasi Manusia Republik Indonesia Nomor M.HH-11.OT.01.01 Tahun 2009 tentang Organisasi dan Tata Kerja Rumah Detensi Imigrasi ${ }^{50}$ Pasal 1, dijelaskan bahwa RUDENIM merupakan tempat penampungan sementara bagi orang asing yang melanggar peraturan perundang-undangan yang dikenakan tindakan keimigrasian dan menunggu proses pemulangan atau deportasi. Jika mengingat adanya prinsip non-refoulment dan prinsip non-penalization yang telah dijelaskan sebelumnya serta merujuk pada peraturan tersebut, penggunaan RUDENIM sebagai tempat sementara untuk pengungsi merupakan hal yang seharusnya tidak dilakukan. Penggunaan RUDENIM sebagai tempat penampungan dikarenakan keterbatasan penampungan yang dimiliki UNHCR. Sejauh ini, UNHCR memiliki lima penampungan pengungsi di Jakarta yang diprioritaskan untuk pengungsi yang beRkondisi khusus seperti anak-anak yang datang tanpa pendamping keluarga dan orang tua. ${ }^{51}$ Dalam menanggapi permasalahan ini, koordinasi antara Indonesia dan UNHCR harus lebih ditingkatkan untuk mencari solusi terkait penampungan yang selayaknya bagi pengungsi.

Permasalahan ketiga adalah lembaga-lembaga yang terlibat dalam penanganan pengungsi belum mengenal dengan baik rekan kerjasamanya. Hal tersebut dapat dilihat pada BAGAN III dan BAGAN IV tentang alur penentuan/penetapan status pengungsi di Indonesia dalam BAB sebelumnya. Bahwa dalam alur yang didapat melalui wawancara pada BAGAN III, pihak Imigrasi belum melibatkan unsur Kementerian Luar Negeri Republik Indonesia yang merupakan narahubung

\footnotetext{
${ }^{50}$ Peraturan Menteri Hukum dan Hak Asasi Manusia Republik Indonesia Nomor M.HH-11. OT.01.01 Tahun 2009 tentang Organisasi dan Tata Kerja Rumah Detensi Imigrasi (Berita Negara Republik Indonesia Tahun 2009 Nomor 264).

51 Riva Dessthania Suastha, UNHCR: Rudenim Bukan Tempat Tampung Pengungsi Asing, https://www.cnnindonesia.com/internasional/20180405142110-106-288510/unhcr-rudenim-bukan-tempat-tampung-pengungsi-asing , 5 April 2018, accessed pada 28 Juni 2018.
} 
terhadap organisasi Internasional seperti UNHCR. Sebaliknya, dalam BAGAN IV tidak disebutkan peran pihak imigrasi dalam penanganan pengungsi yang memasuki Indonesia sebagai negara transit. Hal ini membuktikan belum adanya koordinasi dan pemahaman yang kuat di antara lembaga-lembaga dalam penanganan masalah pengungsi. Selain itu, dalam kedua bagan juga tidak dicantumkan mengenai peran IOM secara jelas dalam penanganan pengungsi. Sedangkan dalam tujuannya IOM bertanggungjawab untuk mengenalkan migrasi yang lebih tertib termasuk migrasi oleh pengungsi, yang membutuhkan layanan migrasi internasional.

Dapat kita ketahui pula bahwa para pihak tergabung dalam Desk Koordinasi P2MP2S dimana para pihak berkoordinasi untuk penanganan pengungsi di Indoneia. Namun dengan munculnya permasalahan ketiga tersebut, dapat diartikan bahwa koordinasi antara Indonesia dengan lembaga-lembaga terkait belum berjalan dengan baik. Tentunya permasalahan ini menuntut diskusi lebih jauh dari Indonesia dan lembaga-lembaga tersebut agar tercipta hubungan dan koordinasi yang lebih baik lagi. Berikut penulis mengusulkan alur komprehensif dalam penanganan pengungsi di Indonesia

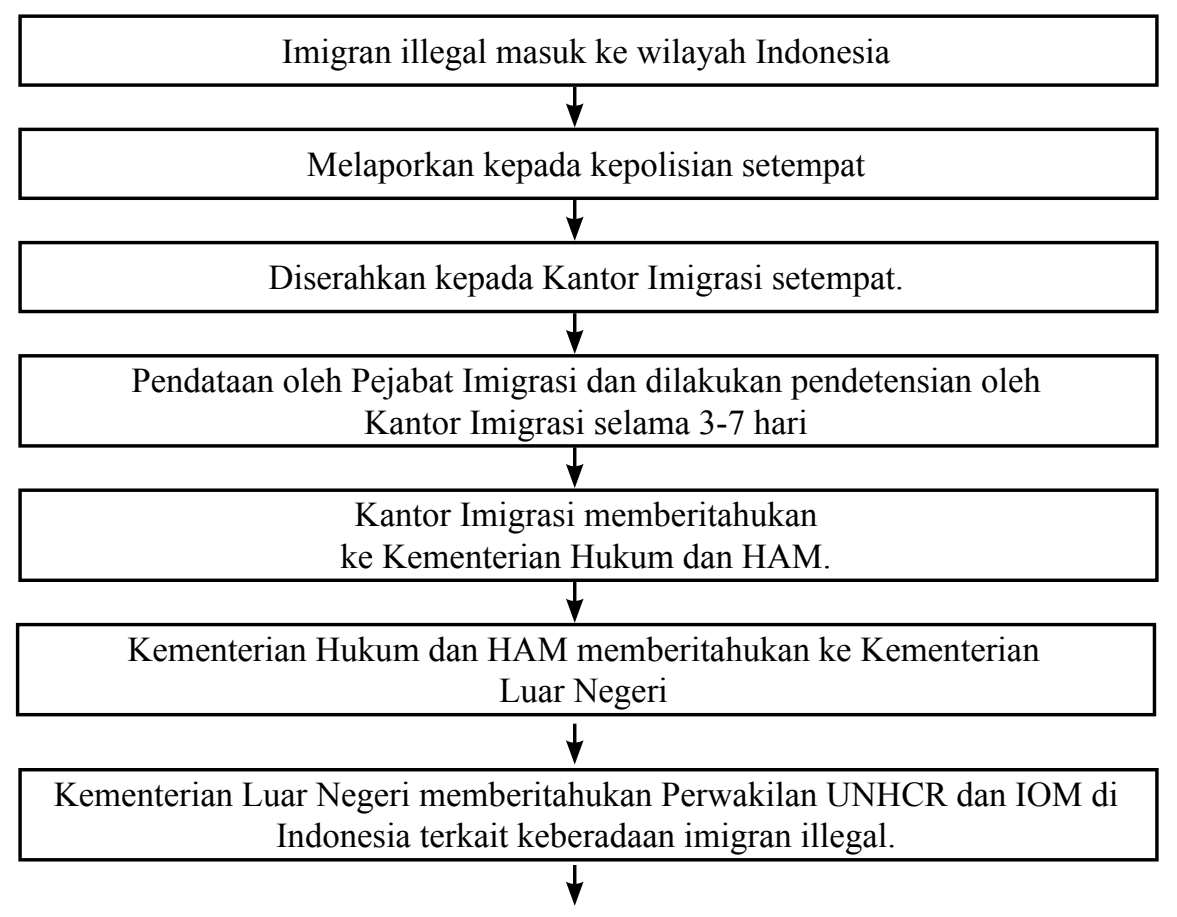


UNHCR dan IOM bekerjasama dalam melakukan pendataan terhadap imigran illegal tersebut.

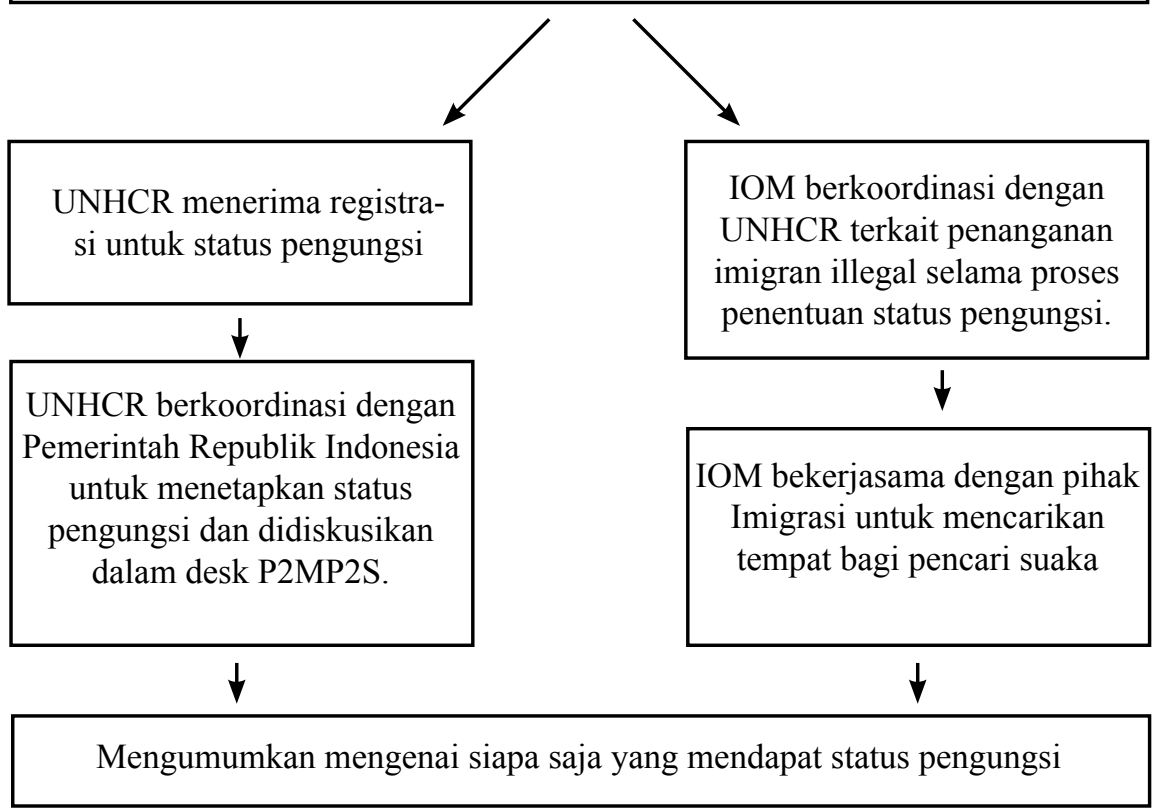

\section{$\downarrow$}

Kementerian Luar Negeri, Kementerian Hukum dan HAM, UNHCR dan

IOM berkoordinasi terkait tempat penampungan sementara bagi pengungsi (RUDENIM sebagai opsi terakhir)

UNHCR dan IOM berkoordinasi terkait pembiayaan hal-hal yang berkaitan dengan pengungsi termasuk tempat penampungan, kebutuhan sehari-sehari dan hal yang esensial lainnya bagi pengungsi.

Kementerian Luar Negeri, Kementerian Hukum dan HAM, UNHCR dan IOM berkoordinasi terkait masa tunggu yang diberlakukan seragam bagi seluruh pengungsi sampai dengan resettlement atau repatriasi sukarela.

UNHCR dan IOM membantu proses resettlement atau repatriasi sukarela.

Dalam proses repatriasi sukarela IOM akan membantu dana terkait proses tersebut

\section{$\downarrow$}

Pendampingan akan dilakukan oleh UNHCR dan IOM dalam kurun waktu 6 bulan-1 tahun. Hal tersebut dilakukan untuk membantu pengungsi beradaptasi kembali di negara asalnya.
Dalam proses resettlement, IOM akan membantu dana terkait proses tersebut

\begin{tabular}{|c|}
$\downarrow$ \\
\hline Pendampingan akan dilakukan \\
oleh UNHCR dan IOM dalam \\
kurun waktu 6 bulan. Hal \\
tersebut dilakukan untuk \\
membantu pengungsi beradapta- \\
si di negara ketiga. \\
\hline
\end{tabular}


Permasalahan-permasalahan di atas memunculkan urgensi bagi Indonesia untuk meningkatkan kerjasama dengan lembaga-lembaga terkait dalam penanganan pengungsi di wilayah Indonesia. Kerjasama tersebut tidak hanya terbatas pada organisasi internasional yang mempunyai mandate langsung untuk penanganan pengungsi. Kesempatan bekerjasama ini juga terbuka bagi lembaga-lembaga lain yang mempunyai prospek untuk turut serta dalam penanganan pengungsi di wilayah Indonesia. Dengan dilakukannya peningkatan kerjasama tersebut, diharapkan solusi permanen untuk pengungsi dapat segera dirumuskan dan diterapkan untuk mengurangi jumlah pengungsi yang semakin bertambah.

\section{Kesimpulan}

Instrumen yang mengatur mengenai penanganan pengungsi secara internasional adalah Konvensi Jenewa 1951 dan Protokol New York 1967. Terkait dengan penanganan terhadap pengungsi, dilakukan oleh organisasi internasional seperti UNHCR atau negara pihak dari Konvensi Jenewa 1951 dan/atau Protocol New York 1967. Mengingat Indonesia bukan merupakan negara pihak dari Konvensi Jenewa 1951dan/atau Protokol New York 1967, penanganan pengungsi di Indonesia merupakan hasil kerjasama dengan lembaga-lembaga yang berkaitan dengan penanganan pengungsi. Beberapa lembaga yang turut andil memberikan peran dalam penanganan pengungsi adalah UNHCR, IOM, dan ICRC. Kerjasama antara Indonesia dengan ketiga lembaga tersebut telah terjalin dan diwujudkan dalam hal yang konkret baik itu berbentuk perjanjian antara kedua belah pihak atau kegiatan sebagai hasil kolaborasi. Kerjasama tersebut telah berlangsung hingga saat ini. Namun, dalam perjalanannya muncul beberapa permasalahan dalam proses penanganan pengungsi. Oleh karena itu, diperlukan peningkatan kerjasama antara Indonesia dengan lembaga-lembaga terkait. Peningkatan kerjasama tersebut diharapkan dapat mempercepat perumusan solusi permanen bagi pengungsi. 


\section{Daftar Bacaan}

\section{Buku}

Amidjojo. Sri Badin, Perlindungan Hukum Terhadap Pengungsi Berdasarkan Konvensi Jenewa 1951, Badan Pembinaan Hukum Nasional Departemen Kehakiman dan Hak Asasi Manusia Republik Indonesia (2004).

Goodwin-gill. Guy S., The Refugee in International Law Second Edition (Clarendon Press 1998).

Patrnogic. Jovan, Introduction to International Refugee Law, International Institute of Humanitarian Law (San Remo 1996).

Romsan. Achmad et al., Pengantar Hukum Pengungsi Internasional (UNHCR 2003).

Wagiman, Hukum Pengungsi Internasional (Sinar Grafika 2012).

\section{Modul}

UNHCR, Procedural Standards for Refugee Status Determination under UNHCR's Mandate (UNHCR 2005).

UNHCR, Training Module RLD I, An Introduction to the International Protection of Refugees (UNHCR 1992).

\section{Skripsi}

Ningrum. Pratiwi, Perlindungan Hukum Bagi Pengungsi, Skripsi, Fakultas Hukum Universitas Airlangga 2013.

Jatyputri, Winner Nabila, Penerapan Prinsip Non-Discrimination bagi Pengungsi Rohingya di Indonesia, Skripsi, Fakultas Hukum Universitas Airlangga 2015.

\section{Jurnal}

Fachrurrahman, Reza, Penerapan Prinsip Non-Refoulment Terhadap Pengungsi di Indonesia Sebagai Negara Yang Bukan Merupakan Peserta Konvensi Jenewa Tahun 1951 Mengenai Status Pengungsi, JOM Fakultas Hukum, Vol. III, No.2, Oktober 2016.

Fandik, Moh., Penampungan Orang Vietnam di Pulau Galang 1975-1979, AVATARA e-Journal Pendidikan Sejarah Universitas Negeri Surabaya, Vol. 1, No.1, Januari 2013. 
Riyanto, Sigit Prinsip Non-Refoulment dan Relevansinya dalam Sistem Hukum Internasional, mimbar hukum, Vol. 22, Nomor 3, Oktober 2010.

Urgensi Legislasi Hukum Pengungsi dan Kendalanya di Indonesia, Indonesian Journal of International Law, Vol. 2, No. 1, 2004.

\section{Artikel}

Final Act of the United Nations Conference of Plenipotentiaries on the Status of Refugees and Stateless Persons, Konvensi Jenewa 1951 dan Protokol New York 1967.

Introductory Note by the Office of the United Nations High Commissioner for Refugees (UNHCR), Konvensi Jenewa 1951 dan Protokol New York 1967.

\section{Laman}

Bali Process, Ministerial Conference and Senior Officials Meetings https://www. baliprocess.net/ministerial-conferences-and-senior-officials-meetings/ , Maret 2016, accessed pada 25 Juni 2018

ICRC, Babinkum TNI dan ICRC Formalkan Kerjasama, http://blogs.icrc.org/ indonesia/babinkum-tni-dan-icrc-formalkan-kerjasama/, 7 September 2011, accessed pada 26 Juni 2018

-ICRC Perkuat Kerjasama Akademik dengan Universitas Syah Kuala Aceh, $\quad \mathrm{http}: / /$ blogs.icrc.org/indonesia/icrc-perkuat-kerjasama-akademikdengan-universitas-syah-kuala-aceh/ , 7 September 2015, accessed pada 27 Juni 2018.

-Wawancara Kepala Delegasi Regional ICRC: Kenapa ICRC Masih Ada di Indonesia?, http://blogs.icrc.org/indonesia/wawancara-kepala-delegasiregional-icrc-kenapa-icrc-masih-ada-di-indonesial 7 September 2011, accessed pada 26 Juni 2018.

IOM, January 2014 Newsletter "IOM di Indonesia", http://indonesia.iom.int/sites/ default/files/January\%202014\%20Newsletter\%20Indonesian.pdf, Januari 2014, accessed pada 25 Juni 2018.

Kanwil NTT, Beerita Satuan Kerja Direktorat Jenderal Imigrasi Bersama IOM Adakan Pelatihan dan Sosialisasi di Rudenim Kupang, https://ntt. kemenkumham.go.id/berita-kanwil/berita-upt/3147- direktorat-jenderalimigrasi-bersama-iom-adakan-pelatihan-dan-sosialisasi-di-udenim-kupang , 13 Juli 2017, accessed pada 25 Juni 2018.

Kementerian Luar Negeri Republik Indonesia, Bali Process Sepakati Mekanisme 
untuk Percepa Penanganan Migran Ireguler di Kawasan, https://www.kemlu. go.id/id/berita/Pages/Bali-Process-Sepakati-Mekanisme-untuk-PercepatPenangangan-Migran-Ireguler-di-Kawasan.aspx, 23 Maret 2016, accessed pada tanggal 25 Juni 2018.

Pemerintah Indonesia Tandatangani Naskah Pengaturan Kerjasama untuk Penanganan Masalah Pengungsi, https://www.kemlu.go.id/id/berita/siaranpers/Pages/Pemerintah-Indonesia-Tandatangani-Naskah-PengaturanKerjasama-untuk-Penanganan-Masalah-Pengungsi.aspx, 4 Oktober 2000, accessed pada 25 Juni 2018.

Lembaga Studi dan Advokasi Masyarakat (ELSAM), Perlindungan Pengungsi (Refugee) Menurut Hukum Internasional, http://referensi.elsam.orid/ wp-content/uploads/2014/10/Perlindungan-Pengungsi-Refugee-MenurutHukum-Internasional.pdf, Oktober 2014, accessed pada 2 Februari 2018.

Sari, Eva Nila, MoU Komnas HAM dan UNHCR Dorong Perlindungan Pengungsi dan Pencari Suaka, https:// www. komnasham.go.id/ index.php/ news/2015/7/28/173/mou-komnas-ham-dan-unhcr-dorong-perlindunganpengungsi-dan-pencari-suaka.html , 28 Juli 2015, accessed pada 23 Juni 2018.

Suryono, Mitra, UNHCR dan Komisi Nasional Hak Asasi Manusia Indonesia Bekerja Sana untuk Lindungi Hak Asasi Manusia bagi Pengungsi dan Lainnya, http:// www.unhcr. org/ id/ wp-content/ uploads/ sites/42/2017/05/ Siaran-Pers-MoU-Signing-KomNasHAM.pdf , 28 Juli 2015, accessed pada 23 Juni 2018.

Suastha, Riva Dessthania, UNHCR: Rudenim Bukan Tempat Tampung Pengungsi Asing, https://www.cnnindonesia.com/ internasional/20180405142110-106288510/ unhcr-rudenim-bukan-tempat-tampung-pengungsi-asing, 5 April 2018, accessed pada 28 Juni 2018.

Tempo.co, Tak Lagi Usir Pengungsi, Australia Tunduk pada Bali Process, https:// dunia.tempo.co/read/729969/tak-lagi-usir-pengungsi-australia-tundukpada-bali-process , 22 Desember 2015, accessed pada 25 Juni 2018

United Nations General Assembly (UNGA) Fifth Session, General Assembly Resolution No. 428 (V) 14 December 1950, 14 December 1950, http://www. unhcr.org/refworld/docid/3b00f08a27.html, accessed pada 8 November 2017

UNHCR, Tentang United Nations High Commisioner for Refugees, http://www. unhcr.org/id/, accessed pada tanggal 8 November 2017. 


\section{Perundang-undangan}

Undang-Undang Nomor 37 Tahun 1999 tentang Hubungan Luar Negeri (Lembaran Negara Republik Indonesia Tahun 1999 Nomor 156, Tambahan Lembaran Negara Republik Indonesia Nomor 3882).

Peraturan Menteri Hukum dan Hak Asasi Manusia Republik Indonesia Nomor M.HH-11.OT.01.01 Tahun 2009 tentang Organisasi dan Tata Kerja Rumah Detensi Imigrasi (Berita Negara Republik Indonesia Tahun 2009 Nomor 264).

Convention Relating to the Status of Refugees 1951, Registration Number 2545, UNTS Volume Number 189, entry into force on 22 April 1954.

Universal Declaration of Human Rights 1948, proclaimed by United Nations General Assembly Resolution No. 217 A, 10 December 1948.

Statute of the Office of the United Nations High Commissioner for Refugees (UNHCR), proclaimed by UNGA Resolution 428 (V0 14 December 1950.

HOW TO CITE: Mohamad Iqbal Jamilurir Rachman, 'Kerjasama Indonesia Dengan Lembaga-Lembaga Terkait Dalam Penanganan Pengungsi' (2018) Vol. 1 No. 1 Jurist-Diction. 